\title{
DOMICÍLIO ELEITORAL E A MASSA DE MANOBRA NAS ELEIÇÕES
}

\section{MUNICI}

\author{
Marcela Silva Almendros ${ }^{1}$ \\ Luiz Nunes Pegoraro ${ }^{2}$
}

\begin{abstract}
Resumo: Este trabalho aborda as vertentes do instituto domicílio e seus reflexos no direito eleitoral. Para tanto foi traçada a evolução histórica da legislação eleitoral brasileira e foram demonstrados os requisitos para a transferência do título de eleitor, quando foram apresentadas supostas fraudes envolvendo a transferência de títulos eleitorais, destacando o recente caso de centenas de acampados no pequeno município paulista de Iacanga, que solicitaram a mudança de seus domicílios eleitorais e repercutiram diretamente na alteração no elenco eleitoral da cidade. Também foi abordada a importância do voto como instrumento de cidadania.
\end{abstract}

Palavras-chave: Eleições municipais; Domicílio eleitoral; Alteração do domicílio; fraude; massa de manobra

\section{ELECTORAL DOMICILE AND MANAGEMENT MASS IN MUNICIPAL ELECTIONS}

\begin{abstract}
This paper deals with the aspects of the home institute and its effects on electoral law. The historical evolution of the Brazilian electoral legislation was traced and the requirements for the transfer of the voter registration were demonstrated, when alleged fraud involving the transfer of electoral titles was highlighted, highlighting the recent case of hundreds of camped in the small municipality of Iacanga, in São Paulo, who requested The change of their electoral domiciles and directly impacted the change in the electoral roll of the city. The importance of voting as an instrument of citizenship was also discussed.
\end{abstract}

Keywords: Municipal elections; Electoral domicile; Alteration of domicil; efraudmass of maneuver

\footnotetext{
${ }^{1}$ Mestre em Direito na área de concentração "Sistema Constitucional de garantias de Direitos" do Programa de Pós-Graduação "Stricto Sensu” mantido pela Instituição Toledo de Ensino - Ite-Bauru. Endereço para acessar este CV: http://lattes.cnpq.br/8353246166049889 prof.almendros@gmail.com

${ }^{2}$ Doutor em Ciências da Reabilitação pela USP; Mestre em Direito Constitucional pela Instituição Toledo de Ensino e Especialista em Direito Público pela ITE; Coordenador do Curso de Direito Administrativo e Constitucional da ITE de Bauru. Endereço para acessar este CV: http://lattes.cnpq.br/7275750680267835. professor@pegoraros.com.br
} 


\section{INTRODUÇÃO}

O tema "domicílio eleitoral" muito interessa aos eleitores, em especial às vésperas das eleições municipais. Temos por objetivo fazer uma singela análise sobre a evolução histórica da legislação eleitoral, a interpretação do instituto do domicílio, bem como a possibilidade de sua transferência. Abordaremos também o sistema de fraude eleitoral que ocorre principalmente em cidades pequenas, trazendo à tona a fragilidade da legislação, a insegurança jurídica e os desafios frente à crise do sentimento de democracia. Focaremos a sociedade e os movimentos sociais que percorrem o país valendo-se da brecha legal para escolherem o domicílio eleitoral, o que refletirá diretamente no resultado de uma eleição municipal. Esses movimentos sociais surgem como verdadeira massa de manobra que barganham vantagens de todos os tipos em troca da fixação do domicílio eleitoral. Será utilizado o método dedutivo.

\section{A EVOLUÇÃO HISTÓRICA DA LEGISLAÇÃO ELEITORAL ACOMPANHANDO AS CONSTITUIÇÕES BRASILEIRAS}

\subsection{A Constituição de 1824 (Brasil Império)}

Considerada pelos historiadores como uma imposição do Imperador Dom Pedro I, esta Carta, datada de 25 de março de 1824, estabelecia 179 artigos. Entre muitas medidas importantes dessa Constituição, destaca-se o fortalecimento do poder pessoal do Imperador, com a criação do Poder Moderador, que por sua vez estava acima dos Poderes Executivo, Legislativo e Judiciário (PONTUAL, 2017).

A constituição de 1824 regulamentou as eleições indiretas para Senadores e Deputados, bem como sobre quem era elegível e quem poderia votar nas Assembleias Paroquiais.

Em 1842 foi instituído o alistamento prévio e a eleição da mesa, bem como proibiu o voto por procuração. A primeira lei assinada pelo Imperador revogou todas as anteriores, e estabelecia uma data para eleições simultâneas em todo o Império. A segunda lei que tratava de desincompatibilização foi substituída pela Lei do Terço, Decreto n ${ }^{\circ} 2.675$, de 20 de outubro de 1875, que determinava que as eleições para Deputados à Assembleia Geral e para membros das Assembleias Legislativas fossem realizadas por províncias. Determinava ainda que os partidos 
ou coligações vitoriosos preenchessem dois terços dos cargos, ficando o restante ocupado por partidos minoritários, além de instituir o título de eleitor (CERQUEIRA, 2002, p.61 e 62).

Neste período, o direito ao voto era concedido somente aos homens livres e proprietários, de acordo com seu nível de renda, fixado na quantia líquida anual de cem mil réis por bens de raiz, indústria, comércio ou empregos. Para ser eleito, o cidadão também tinha que comprovar renda mínima proporcional ao cargo pretendido (PONTUAL, 2017). Em 1881 a Lei Saraiva delegou o alistamento de eleitores à Magistratura.

\subsection{A Constituição de 1891 (Brasil República)}

Em 1889 temos a Proclamação da República e em 1891 há a promulgação da primeira Constituição da República, onde advém o sufrágio direto, bem como candidatos eleitos através da maioria absoluta de votos (TSE, 2016).

Na primeira eleição direta para Presidente da República foi eleito Prudente de Morais. Somente votavam os homens maiores de 21 anos. Os analfabetos, religiosos e militares não votavam, assim como as mulheres. O voto não era secreto, mas o chamado "voto de cabresto".

As principais inovações dessa nova Constituição são: instituição da forma federativa de Estado e da forma republicana de governo; estabelecimento da independência dos Poderes Executivo, Legislativo e Judiciário; criação do sufrágio com menos restrições, impedindo ainda o voto aos mendigos e analfabetos; separação entre a Igreja e o Estado, não sendo mais assegurado à religião católica o status de religião oficial; e instituição do habeas corpus (garantia concedida sempre que alguém estiver sofrendo ou ameaçado de sofrer violência ou coação em seu direito de locomoção (ir, vir e permanecer), por ilegalidade ou abuso de poder) (PONTUAL, 2017).

A ideia de que o Poder Judiciário deveria ser o responsável pela maior parte dos trabalhos eleitorais começa a ser pensada no Império e ganha força no século XX. Em 1916 a Lei $\mathrm{n}^{\circ} 3.139$ tornou o preparo do alistamento eleitoral responsabilidade do Poder Judiciário.

Em 1932 o primeiro Código Eleitoral criou a Justiça Eleitoral (Decreto 21.076) para cuidar de todos os trabalhos eleitorais: alistamento, organização das mesas de votação, apuração dos votos, reconhecimento e proclamação dos eleitos, bem como o julgamento de questões que envolviam matéria eleitoral. Surge a adoção do voto secreto, a adoção do voto feminino e a votação por meio de cédulas e urnas de madeira. Regulamentou-se em todo o país as eleições 
federais, estaduais e municipais. Aqui, o domicílio eleitoral ficava a critério do eleitor, que por sua vez, era parte legítima para ação penal sobre crimes eleitorais.

Esse Decreto cria Tribunal Superior de Justiça Eleitoral (o atual Tribunal Superior Eleitoral - TSE), instalado em 20 de maio do mesmo ano, em um prédio na Avenida Rio

Branco, centro do Rio de Janeiro. Seu primeiro presidente foi o Ministro Hermenegildo Rodrigues de Barros.

\subsection{A Constituição de 1934 (Segunda República)}

Essa Constituição sofreu três emendas em dezembro de 1935, destinadas a reforçar a segurança do Estado e as atribuições do Poder Executivo, para coibir, segundo o texto, "movimento subversivo das instituições políticas e sociais" (PONTUAL, 2017).

Em 1935, tivemos a edição do segundo Código Eleitoral, que por sua vez seguem as diretrizes constitucionais da Carta Magna de 1934. Aqui, ocorre a alteração da regra do domicílio eleitoral, ficando então o eleitor restrito a coincidir o domicílio civil com o domicílio eleitoral.

\subsection{A Constituição de 1937 (Estado Novo)}

Cinco anos após ser constituída, já no período de Ditadura Militar, a Justiça Eleitoral é drasticamente extinta pela Constituição Federal, atribuindo-se à União, privativamente, o poder de legislar sobre matéria eleitoral.

Segundo Melo Filho (2013): O golpe ditatorial de 1937 atingiu profundamente a estrutura da justiça eleitoral, que chegou a ser extinta pela Constituição Federal outorgada no mesmo ano do movimento golpista. Só em 1945, com a edição da Lei Constitucional no 9, de 28 de fevereiro de 1945, é que se tornou possível a recriação da justiça eleitoral como órgão autônomo do Poder Judiciário, o que se efetivou através do Decreto-Lei 7.586, de 28 de maio de 1945. Há uma profunda divergência doutrinária acerca do Decreto-Lei 7.586, de 28 de maio de 1945, conhecido como "Lei Agamenon Magalhães”, que, para alguns, a exemplo de Pinto Ferreira, constituiu o terceiro código eleitoral do Brasil; e, para outros, como Antônio Roque Citadini e Joel J. Cândido, não passou de uma lei eleitoral, embora revestida de suma importância para a nossa história eleitoral.

Esta Carta trouxe diversas medidas, como a pena de morte; supressão da liberdade partidária e da liberdade de imprensa; anulação da independência dos Poderes Legislativo e 
Judiciário; restrição das prerrogativas do Congresso Nacional; permissão para suspensão da imunidade parlamentar; prisão e exílio de opositores do governo; e eleição indireta para presidente da República, com mandato de seis anos (PONTUAL, 2017).

Após a derrota da Alemanha na Segunda Guerra Mundial, o Brasil sofreu as consequências da derrocada do nazifascismo. Getúlio Vargas entrega o poder ao então presidente do Supremo Tribunal Federal (STF), José Linhares, em 1945.

O novo presidente constituiu outro ministério e revogou o artigo 167 da Constituição e também o Tribunal de Segurança Constitucional. Ao fim de 1945 as eleições realizadas para a Presidência da República deram vitória ao general Eurico Gaspar Dutra, empossado em 31 de outubro de 1946, que governou o país por decretos-lei, enquanto preparava-se uma nova Constituição (PONTUAL, 2017).

A Justiça Eleitoral só foi restabelecida em 28 de maio de 1945, pelo Decreto-Lei $\mathrm{n}^{\circ} 7.586 / 1945$. No dia $1^{\circ}$ de junho do mesmo ano, o Tribunal foi instalado no Palácio Monroe, no Rio de Janeiro, sob a presidência do Ministro José Linhares.

\subsection{A Constituição de 1946}

Entre as principais medidas trazidas pela Constituição de 1946, temos o restabelecimento dos direitos individuais, o fim da censura e da pena de morte, a volta da independência do Executivo, Legislativo e Judiciário e restabeleceu o equilíbrio entre esses poderes, dando autonomia a estados e municípios. Foi instituída eleição direta para Presidente da República, com mandato de cinco anos e a incorporação da Justiça do Trabalho e do Tribunal Federal de Recursos ao Poder Judiciário. Estabeleceu-se a pluralidade partidária; direito de greve e livre associação sindical.

Destaca-se, entre as emendas promulgadas à Carta de 1946, o chamado ato adicional, de 02 de setembro de 1961, que instituiu o regime parlamentarista. Essa emenda foi motivada pela crise político-militar após a renúncia de Jânio Quadros, então presidente do país. Como essa emenda previa consulta popular posterior, por meio de plebiscito, realizado em janeiro de 1963, o país retomou o regime presidencialista, escolhido pela população, restaurando, portanto, os poderes tradicionais conferidos ao presidente da República (PONTUAL, 2017).

Em 1950 temos a edição do terceiro Código Eleitoral, segundo o qual os Juízes tiveram seus papéis ampliados. O golpe militar edificou a edição da Constituição de 1967 que manteve a justiça eleitoral como órgão autônomo do Poder Judiciário. Em abril de 1960, em virtude da 
mudança da capital federal, o TSE foi instalado em Brasília, em um dos edifícios da Esplanada dos Ministérios. Em 1965 foi aprovado o atual Código Eleitoral através da Lei nº 4.737/65.

\subsection{A Constituição de 1967 (Regime Militar)}

Autoritarismo e segurança nacional eram palavras de ordem durante o contexto predominante desta época, amparado no regime militar instalado em 1964, que conservou o Congresso Nacional, mas dominava e controlava o Legislativo. Essa Constituição foi emendada por sucessiva expedição de Atos Institucionais (AIs), que serviram de mecanismos de legitimação e legalização das ações políticas dos militares, dando a eles poderes extraconstitucionais. Entre outras medidas do AI-5, destacam-se: suspensão de qualquer reunião de cunho político; censura aos meios de comunicação, estendendo-se à música, ao teatro e ao cinema; suspensão do habeas corpus para os chamados crimes políticos; decretação do estado de sítio pelo presidente da República em qualquer dos casos previstos na Constituição; e autorização para intervenção em estados e municípios (PONTUAL, 2017).

\subsection{A Constituição de 1988 (Constituição Cidadã)}

A Constituição de 1988 inaugurou um novo arcabouço jurídico-institucional no país, com ampliação das liberdades civis e os direitos e garantias individuais. Consagrou cláusulas transformadoras, concedendo direito de voto aos analfabetos e aos jovens de 16 a 17 anos, além de restabelecer as eleições diretas para Presidente da República e consagrou o voto facultativo para os analfabetos e os maiores de 16 anos.

Em 1989 ocorre a primeira eleição direta para Presidente da República após o golpe de 1964, e em 1990 a edição da Lei das Inelegibilidades, a LC nº 64/90. Em 1995 é aprovada a Lei dos Partidos Políticos (Lei 9.096), enquanto que em 1996, nas eleições municipais, a Justiça Eleitoral iniciou o processo de informatização da votação, dando condições a 33 milhões de eleitores de utilizarem a urna eletrônica. Em 1997 foi aprovada a Lei Geral das Eleições (Lei no 9.504 /97) e a emenda da Reeleição (EC n 16/97).

Em 2006 ocorreu a primeira Minirreforma Eleitoral, tornando mais rígidas as regras sobre propaganda eleitoral, financiamento, e prestação de contas das campanhas eleitorais (Lei $\mathrm{n}^{\mathrm{o}}$ 11.300/06). A segunda minirreforma Eleitoral ocorreu em 2009, quando foram normatizadas diversas regras criadas pela jurisprudência do TSE, além da liberação da propaganda eleitoral na internet por meio de blogs, redes sociais, sítios de mensagens instantâneas e assemelhados 
(Lei $n^{\circ}$ 12.034/09). Em 2010 foi aprovada a Lei da Ficha Limpa, ampliando o rol de causas de inelegibilidade e unificando em oito anos todos os prazos de inelegibilidade ( $\mathrm{LC} \mathrm{n}^{\circ}$ 135/2010). Por fim, em 2010 ocorre o início da implantação do sistema de identificação biométrica por meio da coleta das impressões digitais do eleitor.

\section{DOMICÍLIO}

O domicílio é juridicamente relevante, pois é com base nele que os indivíduos contrairão obrigações e exercerão direitos. Ilustrando sua importância, é nesse local que o cidadão centraliza seus negócios, responde às ações cíveis e até às criminais. Percebe-se, então, que o conceito de domicílio é de grande influência tanto para o Direito Civil quanto para o Direito Penal. Porém, não menos importante, será, também, de grande valia para o Direito Eleitoral.

Domicílio, no antigo Direito Romano, tinha seu conceito atrelado àqueles que possuíam propriedade fundiária. É o Local onde o indivíduo se fixa com estabilidade. Em sentido amplo, domicílio também abrange o conceito de residência, moradia, e pode ser entendido como o local onde a pessoa habita atualmente ou simplesmente permanece (VENOSA, 2015, p. 222, 223). Para Silva (1973, p. 306), domicílio tem seu significado em sentido lato, bem como na acepção jurídica. Vejamos:

[...] é, em sentido lato, empregado para designar o lugar em que temos nossa habitação ordinária ou em que mantemos a nossa residência habitual.

Mas, na acepção propriamente jurídica, domicílio tem significação mais restrita. E, assim, indica o centro ou sede de atividades de uma pessoa, o lugar em que mantém o seu estabelecimento ou fixa a sua residência com ânimo definitivo.

Interessante o olhar da doutrinadora Maria Helena Diniz (1990, p. 108) sobre o conceito de domicílio, no que tange à "presunção": [...] O domicílio é a sede jurídica da pessoa, onde ela se presume presente para efeitos de direito e onde exerce ou pratica, habitualmente, seus atos e negócios jurídicos.

$\mathrm{Na}$ atualidade, domicílio é o local onde uma pessoa pode ser encontrada para os efeitos jurídicos, para os efeitos da vida civil, trata de um conceito jurídico, local onde a pessoa exerce sua residência com animus definitivo, e não apenas com a intenção de permanecer, mas de permanecer com âmbito definitivo. 
O Código Civil de 2002 ampliou o domicílio, admitindo o domicílio plural, que nada mais é do que a possiblidade de ter mais de um domicílio: a pessoa pode morar uma parte da semana em uma cidade, e na outra parte da semana em outro lugar. Ao lado disso, o Código Civil de 2002 também contempla a hipótese do domicílio profissional, que é o local onde a pessoa exerce seu trabalho. De acordo com o código, o domicílio profissional só pode ser evocado em razão do ofício. No caso de uma pessoa morar em uma cidade e trabalhar em outra, é preciso ter certa cautela pois o local onde a pessoa mora pode ser evocado para todas as obrigações, inclusive as profissionais. Já o domicílio profissional é restrito, e somente pode ser demandado nesse domicílio para seu ofício. Em nenhuma hipótese o domicílio profissional irá excluir o domicílio natural da pessoa. O Código Civil também possibilita que a pessoa tenha um domicílio profissional plural.

No entanto, domicílio eleitoral e domicílio civil são conceitos distintos que possuem características próprias no Código Civil e no Código Eleitoral. A jurisprudência não caracteriza o domicílio eleitoral com os mesmos requisitos do civil, conforme Ac.-TSE n 16.397/2000 e 18.124/2000: “o conceito de domicílio eleitoral não se confunde,necessariamente, com o de domicílio civil; aquele, mais flexível e elástico, identifica-se com a residência e o lugar onde o interessado tem vínculos - políticos, sociais, patrimoniais, negócios”.

Domicílio civil é o local em que a pessoa se estabelece com ânimo definitivo, dmitindo até mesmo a possibilidade de múltiplos domicílios, caso a pessoa tenha mais de uma residência e alterne a moradia, na legislação eleitoral o conceito é diferente. Já, domicílio eleitoral, embora deva ser único, pode ser também o local em que o eleitor tenha vínculo profissional, familiar ou político. O parágrafo único do art. 42 do Código Eleitoral, atesta que "é domicílio eleitoral o lugar de residência ou moradia do requerente, e, verificado ter o alistando mais de uma, considerar-se-á domicílio qualquer delas."

Essa diferenciação evidencia consequências benéficas aos eleitores e aos candidatos, ois permite uma maleabilidade que não seria possível caso a legislação eleitoral se mantivesse irredutível ao conceito de domicílio civil.

Perceba que é perfeitamente possível alguém querer votar em local diverso de onde efetivamente more, por qualquer motivo capaz de manter o vínculo especial. A moradia em determinado lugar não significa o rompimento total dos vínculos com a antiga residência, que, aliás, podem ser mais fortes que o novo vínculo. Imagine, por exemplo, o caso de alguém que se mude apenas para cursar nível superior ou para trabalhar temporariamente. Os vínculos com 
sua origem não são desfeitos e, às vezes, podem até ser bem mais robustos que o motivo da mudança. Portanto, a rigidez do domicílio civil talvez pudesse entrar em conflito com a liberdade de exercer o voto onde o eleitor tenha algum dos vínculos mencionados nos parágrafos anteriores.

Assim, estas são as justificativas de o conceito de domicílio ser mais abrangente para o Direito Eleitoral, permitindo que os eleitores votem onde tenham vínculos reais, ainda que não sejam no município de sua moradia; eliminar possíveis injustiças a quem queira lançar candidatura em local diverso de onde mora, mas que a ele esteja vinculado; e viabilizar aorganização das eleições.

Em que pese o conceito de domicílio eleitoral seja mais amplo, permitindo escolha por parte do eleitor, não há uma liberdade total, pois o eleitor deve demonstrar que ali ele possui o que a lei chama de residência ou moradia. $O$ cidadão tem que ter uma presença física naquela localidade em que pretende se estabelecer como eleitor. Não pode simplesmente se ligar a uma cidade qualquer, por gosto ou opções pessoais e então ali ser eleitor. Ele tem que ter um vínculo. Ilustrando, é comum ao se mudar de cidade ou Estado, o eleitor não transfira o título, como uma forma de se manter vinculado a suas raízes familiares, não querendo perder contato com suas raízes, com sua família.

Nota-se que a amplitude do conceito de domicílio trazida pela legislação eleitoral pode ser perigosa, ainda mais na atual situação em que vivemos tempos críticos, e a crise afeta nosso sentimento democrático.

\section{DOS REQUISITOS PARA A TRANSFERÊNCIA DE DOMICÍLIO ELEITORAL}

Vários dispositivos legais discorrem sobre transferência de domicílio. Inicialmente o artigo 55 do Código Eleitoral (Lei $\mathrm{n}^{\circ}$ 4.737/1965) fala que em caso de mudança de domicílio, cabe ao eleitor requerer ao juiz do novo domicílio sua transferência, juntando o título anterior.

Condiciona o transcurso de pelo menos um ano da inscrição primitiva e residência ínima de três meses no novo domicílio, atestada pela autoridade policial ou provada por outros meios convincentes.

De acordo com a Lei $n^{\circ}$ 9.504/1997, que estabelece normas para eleições, o art. 91 prevê que no caso de transferência para novo domicílio, deverá o eleitor respeitar o prazo de cento e cinquenta dias antes da data da eleição. 
O eleitor ainda, conforme o art. 18 da Resolução nº 21.538/2003, do Tribunal Superior Eleitoral, deverá atentar-se ao prazo de pelo menos um ano do alistamento ou da última transferência, e, ainda, comprovar residência mínima de três meses no novo domicílio, declarada, sob as penas da lei, pelo próprio eleitor, nos moldes do art. $8^{\circ}$, III, da Lei 6.996/82.

Dessa forma, no Direito Eleitoral o domicílio da pessoa determina o local onde a pessoa pode votar e ser votada. Para transferir o título, o eleitor precisa provar que tem um vínculo com o novo domicílio eleitoral. Os documentos aceitos para comprovarem o domicílio eleitoral estão dispostos no art. 65 da Resolução TSE nº 21.538/2003, entre eles, a contas de luz, água ou telefone, nota fiscal ou envelopes de correspondência. Se não tiver nenhum documento no nome, pode utilizar de uma declaração de residência assinada por qualquer pessoa, até mesmo sem nenhuma declaração de vínculo com o eleitor. E aqui está o grande dilema: é esse tipo de declaração que os eleitores se valem para "suposta fraudes" eleitoras.

Em relação a essa declaração, a Lei 7.115/1983, art. $1^{\circ}$, dispõe que: "A declaração destinada a fazer prova de vida, residência, pobreza, dependência econômica, homonímia ou bons antecedentes, quando firmada pelo próprio interessado ou por procurador bastante, e sob as penas da lei, presume-se verdadeira". Corroborando esse raciocínio, a Res.-TSE $n^{\circ}$ 11.917/1984, afirma que as regras de direito probatório contidas na Lei $n^{\circ} 7.115 / 1983$ são aplicáveis ao processo eleitoral, com exceção do processo penal eleitoral.

Caso o eleitor não consiga comprovar os requisitos, não terá seu título transferido.

Isso porque tal transferência não pode ser utilizada como "manobra" eleitoral, ou até mesmo como forma de manipular interesses políticos. É o que acontece. Isso porque como abordado anteriormente, a legislação eleitoral traz certa amplitude para o conceito de domicílio, o que facilita essas fraudes.

\section{CASOS CONCRETOS: MUNICÍPIO DE IACANGA/SP E DE BORÁ/SP}

A hermenêutica na análise do domicílio eleitoral pode trazer sérios problemas para nossa democracia. Em cidades pequenas, principalmente, eleitores podem solicitar a mudança de domicílio eleitoral apenas para obter vantagens próprias, desvirtuando-se totalmente do que deveria ser o instituto do domicílio eleitoral.

A aspiração por uma democracia limpa ainda é o sonho de muitos cidadãos. Cabe aos Magistrados eleitorais a criteriosa análise no caso concreto para afastar situações que não 
tenham amparo no espírito da lei, visando trazer segurança jurídica e efetivação dos ideais democráticos. A democracia é de dentro para fora.

Vivemos tempos de crise de sentimento democrático. Não podemos nos apoderar de "fragmentos" ou "lacunas" na legislação para fraudar uma eleição. Ora, se a legislação é “flácida", ou seja, flexível demais, a questão é se devemos restringir o conceito de domicílio eleitoral ou abranger o conceito de cidadania.

Em Iacanga, interior de São Paulo, a Procuradoria Jurídica do Município denunciou possível fraude. Ainda sem saber ao certo o número de transferências, o Procurador Municipal notificou a Justiça Eleitoral para fornecer os dados, mas existe suspeita de que quinhentos a mil novos eleitores tenham solicitado e conseguido domicílio eleitoral na cidade. A Procuradoria Municipal afirma que estes novos títulos são de pessoas de um determinado acampamento, onde vivem mais de duas mil e quinhentas pessoas. O INCRA emitiu um documento alegando que eles são assentados, porém, ao que consta, não são. Trata-se de uma população volátil, que em determinado dia estão acampados aqui, e outro dia estão acampados lá. Há suspeita de fraude, tendo em vista que essa população de acampados em Iacanga teria representatividade para eleger por exemplo o Prefeito de Iacanga, haja vista que na última eleição a diferença de votos foi de cento e noventa votos entre o primeiro e o segundo colocado. Em Municípios pequenos, pode-se arriscar à dizer que o voto de um eleitor impacta diretamente no resultado final da eleição. Com a alteração de quinhentos a mil títulos eleitorais, efetivamente haverá mudança de um quadro eleitoral, por isso a suspeita de fraude.

As investigações estão apenas começando, pois o Ministério Público paulista recebeu a denúncia, e se houver irregularidades, os responsáveis podem ser penalizados por crime eleitoral, ficando sujeitos a ele os supostos credores das transferências e até mesmo eleitores que aceitaram a fraude.

Vejamos:

A Prefeitura de Iacanga (50 quilômetros de Bauru) aponta suposta fraude na transferência de títulos eleitorais de famílias acampadas em área pública da cidade.

Segundo o Executivo, com apoio de pré-candidatos, sem-terras estariam alterando domicílio eleitoral para o município com base em documento do Instituto Nacional de Colonização e Reforma Agrária (Incra) atestando que eles moram em assentamento, informação que é contestada pela administração.

Na última sexta-feira (1), o secretário de Assuntos Jurídicos de Iacanga, Sebastião de 
Paula Xavier Neto, denunciou o caso à Justiça Eleitoral de Ibitinga. "Entrei com uma petição perante o Tribunal Eleitoral pedindo que fosse oficiado o Ministério Público para investigar e saber se existem alguns pré-candidatos a vereador envolvidos nessa 'maracutaia', que eu chamo de "pedalada eleitoral'", declara.

$\mathrm{O}$ assessor questiona a legalidade do documento fornecido pelo Incra aos sem-terras. "O pessoal do movimento sem terra conseguiu documento emanado do Incra alegando que eram assentados do acampamento Guaricanga-Iacanga", conta. "Em primeiro lugar, Guaricanga não tem nada a ver com Iacanga. E eu juntei certidão da prefeitura dizendo que nós não temos assentamento na cidade de Iacanga”.

Segundo Xavier Neto, até agora, mais de 500 sem-terras que estão acampados há mais de um ano em área pertencente ao DER, localizada às margens da rodovia Cezário José de Castilho (SP-321), já teriam transferido seu título de eleitor para Iacanga. "Eles são invasores de uma área pública. E acampados mediante esbulho possessório", afirma. "Se não existe assentamento, não existe o domicílio eleitoral".

$\mathrm{O}$ assessor revela que mais de 2 mil pessoas moram no acampamento e diz que essa suposta fraude poderia comprometer o processo eleitoral local. "Estão querendo privilegiar uma parcela pequena de pessoas desamparadas, que têm direito do exercício da cidadania, mas onde eles residem. Aqui eles estão descumprindo o direito de cidadania e de livre eleição dos seus representantes de 12 mil pessoas", defende. Por meio de nota, a Superintendência Regional do Incra em São Paulo confirmou que emite documento para aqueles que constam em seu cadastro de famílias acampadas no estado de São Paulo. "Trata-se de uma declaração que atesta a condição de acampado(a), após consulta em nossos arquivos, mediante solicitação da própria pessoa ou coordenação do acampamento", explica.

O Incra diz que as famílias acampadas em Iacanga estão cadastradas para serem incluídas como candidatas a beneficiárias da reforma agrária em assentamentos a serem criados. "O cadastro também serve para identificar famílias em vulnerabilidade social para que sejam acolhidas nas redes de proteção social, como o CadÚnico, e recebimento de cestas básicas. Normalmente, o documento é solicitado para fins escolares ou previdenciários, não cabendo ao Incra definir sua finalidade ou utilização", declara. (GRASIELA, 2016)

Deve ser destacado que só pode requerer domicílio eleitoral quem já é assentado, enão acampado. O domicílio eleitoral exige o ânimo definitivo. O acampado não tem essa “definitividade", já o assentado recebe um título de propriedade, e com este título ele teria uma 
posse definitiva, podendo então por analogia criar raízes no local, e assim haveria possibilidade dele participar do processo eleitoral.

Ora, se por um lado a lei abre precedente para possibilidade de mudança de domicílio eleitoral, como finalidade o caráter "objetivo", por outro lado o instituto "domicílio" acaba se afastando do domicílio estritamente civil.

Em Municípios pequenos, como no presente caso na cidade de Iacanga/SP, cada voto tem impacto diretamente no resultado final da eleição, esta possa acabar por ser decidida por pessoas que em que pese estejam vinculadas com a cidade, não habitam efetivamente o local.

Outro caso extraordinário, é o caso de um município paulista de Borá, que tem mais eleitores do que moradores, efetivamente. Vejamos:

Borá, o município com o menor número de habitantes do estado de São Paulo, tem mais eleitores do que moradores. Os números foram divulgados na terça-feira (30), pelo IBGE. A cidade é a segunda com menos população do Brasil, a primeira é Serra da Saudade, em Minas Gerais. Em quatro anos, Borá ganhou 33 moradores e 143 eleitores.

De acordo com o IBGE, o município tem 838 habitantes e um número bem maior de eleitores. Em 2012, Borá tinha 1071 eleitores, já em 2016, são 1214, segundo estatística do Tribunal Superior Eleitoral.

"Isso é bastante comum por conta do conceito de domicílio eleitoral que é diferente do conselho de domicílio civil. O domicílio eleitoral permite que o eleitor transfira seu título por ter outro tipo de vínculo com o município, por exemplo, o eleitor trabalha em Borá, tem um vínculo familiar. Por exemplo, um estudante. Ele estuda em Marília, só que a família reside em Borá. Então ele quer votar em Borá porque ele tem família lá, tem a confiança, ele conhece os candidatos", explica a abalista judiciária Paula Affonso de Mello Barbosa Tavares.

No Brasil, Borá é a quinta cidade com o menor número de eleitores. Os homens são maioria. Das pessoas que vão as urnas escolher um candidato, os mais jovens, com até 20 anos, representam $5 \%$ do total de eleitores. Já, $12 \%$ tem entre 30 e 34. "O voto é muito importante porque na hora que a gente vai votar tem que estar consciente quem vai por lá, porque não é um dia, dois. São quatro anos", diz a auxiliar de serviços gerais Eliane de Almeida Rodrigues.

O IBGE também divulgou na terça-feira (30) que o Brasil tem 206,1 milhões habitantes (BORÁ, 2016)

Diante desses casos, podemos trazer uma "preocupação hermenêutica" com a literalidade do artigo 55 do Código Eleitoral e o "liberalismo" outorgado ao eleitor sobre a 
transferência de domicílio, em que pese ele seja "responsável" por suas declarações. O problema seria mesmo "hermenêutico" ou "crise de sentimento democrático"?

\section{O VOTO COMO INSTRUMENTO DE CIDADANIA}

Ser cidadão é participar da vida política do país. O voto é a forma mais comum de participação política. É o instrumento que assegura a todo cidadão o direito de escolher os seus representantes e influenciar nas decisões políticas da nação. Apesar de andarem de forma paralela, sufrágio e voto são corriqueiramente usados como sinônimos, mas a Constituição Federal, em seu artigo 14, atribui sentidos diferentes: Art. 14. A soberania popular será exercida pelo sufrágio universal e pelo voto direto e secreto, com valor igual para todos, e, nos termos da lei.

Também é possível verificar a palavra "voto" como "decisão".

Outro termo que se confunde com "sufrágio" e "voto" é o "escrutínio", sendo o sufrágio um direito, o voto o seu exercício e o escrutínio o modo de exercício.

Neste sentido, Fayt (apud SILVA, 2013, p. 352), explica: O sufrágio (do latim sufragium = aprovação, apoio) é, como nota Carlos S. Fayt, um direito público subjetivo de natureza política, que tem o cidadão de eleger, ser eleito e de participar da organização e da atividade do poder estatal. É um direito que decorre diretamente do princípio de que todo poder emana do povo, que o exerce por meio de representantes eleitos ou diretamente. Constitui a instituição fundamental da democracia representativa e é pelo seu exercício que o eleitorado, instrumento técnico do povo, outorga legitimidade aos governantes. Por ele também se exerce diretamente o poder em alguns casos: plebiscito e referendo. Nele consubstancia-se o consentimento do povo que legitima o exercício do poder. E aí esta a função primordial do sufrágio, de que defluem as funções de seleção e nomeação das pessoas que hão de exercer as atividades governamentais.

Dallari (2007, p. 189, 190) acrescenta: Quanto à extensão do direito de votar, podemse fixar dois princípios orientadores, que sintetizam as considerações a respeito das restrições:

a) O eleitor deve ter a possibilidade de agir livremente no momento de votar. Se houver qualquer fator de coação, direta ou indireta, viciando a vontade do eleitor,sua manifestação já não será autentica. E a falta de autenticidade no pronunciamento de muitos eleitores compromete todo o processo eleitoral, retirando-lhe o caráter democrático.

Rev. de Movimentos Sociais e Conflitos| e-ISSN: 2525-9830 | Maranhão | v. 3 | n. 2 | p. 74 - 92 | Jul/Dez. 2017. 
b) O eleitor deve ter consciência da significação de seu ato. Evidentemente, não há de pretender que qualquer colégio eleitoral se componha só de indivíduos dotados de grande cultura política. Mas o que é razoável pretender é que os eleitores, tendo noções fundamentais da organização e das competências que atribuem aos eleitos, votem com responsabilidade. Como é óbvio, o simples fato de alguém atender os requisitos legais para exercer o direito de sufrágio não indica a existência, de fato, de preparo adequado. Cabe aos governos democráticos promover a educação política do eleitorado, através da divulgação sistemática de conhecimentos, por meio de programas escolares, e concedendo ao povo amplas possibilidades de exercício livre dos direitos políticos, aproveitando os efeitos educativos da experiência.

De acordo com Silva (2013, p. 350), a aquisição dos direitos políticos dos cidadãos opera por graus: Pode-se dizer, então, que a cidadania se adquire com a obtenção da qualidade de eleitor, que documentalmente se manifesta na posse do título de eleitor válido. O eleitor é cidadão, é titular da cidadania, embora nem sempre possa exercer todos os direitos políticos. É que o gozo integral destes dependem do preenchimento de condições que só gradativamente se incorporam no cidadão. Não nos parece que isso importe em graus de cidadania política. Esta é atributo jurídico-político que o nacional obtém desde o momento em que se torna eleitor. Mas é certo que alguns direitos políticos só se adquirem em etapas sucessivas. Nestes casos, podemos admitir que a aquisição dos direitos políticos se opera por graus, apenas para denotar o fato de que a plenitude de sua titularidade se processa por etapas: (1) aos 16 anos de idade, o nacional já pode alistar-se tornando-se titular do direito de votar; (2) aos 18 anos, é obrigado a alistar-se tornando-se titular do direito de votar, se não o fizeraaos 16, e do direito de ser eleito para Vereador; (3) aos 21 anos, o cidadão (nacional eleitor) incorpora o direito de ser votado para Deputado Federal, Deputado Estadual ou Deputado Distrital (Distrito Federal), Prefeito, Vice-Prefeito e juiz de paz; (4) aos 30 anos, obtém a possibilidade de ser eleito para Governador e Vice-Governador de Estado e do Distrito Federal; (5) finalmente, aos 35 anos o cidadão chega ao ápice da cidadania formal com o direito de ser votado para Presidente e Vice-Presidente da República e para Senador Federal (art. 14, § $3^{\circ}$ ).

Ora, em que pese o cenário atual de "crise política", não podemos nos afastar de nossos princípios e valores pátrios, nem mesmo nos “contaminar” de forma negativa, utilizando-se da lei para fraudá-la. É tempo de eleições e precisamos nos apossarmos de nossa cidadania para um futuro limpo e digno da nossa democracia. 


\section{CONCLUSÃO}

Após analisar a evolução e o surgimento da legislação eleitoral no Brasil durante suas diversas formas de governo, verificou-se que foi na edição do segundo Código Eleitoral que ocorreu a restrição do domicílio civil com o domicílio eleitoral, época seguida pelo golpe militar.

Constatou-se que há séria lacuna na forma de interpretação do instituto domicílio, que vem sendo utilizada como manobra eleitoral no que tange à transferência de domicílio eleitoral, conforme ilustrado com os municípios paulistas de Iacanga e de Borá.

A repercussão acerca do tema "transferência de domicílio eleitoral" não é recente.

Diversos estudiosos do direito tentam através da lei e dos fatos trazer esse debate para o universo acadêmico com o intuito de alertar os estudantes e tentar se aproximar da resposta, se isso seria um desvirtuamento do conceito de domicílio ou se seria fruto da crise de sentimento democrático vivida na política nos últimos tempos.

O Poder Judiciário deve agir rigorosamente para evitar a utilização dessa eventual lacuna na alteração do domicílio eleitoral, em especial nos pequenos Municípios, onde facilmente essa alteração muda o resultado de uma eleição municipal, partindo inclusive para a seara criminal no caso de declarações falsas ou falta de comprovação de novo domicílio eleitoral no pedido de possível transferência.

É claro que essa discussão não se encerra por aqui. Aguardando as eleições de 2018, paira certo desejo de renovação política. Pelo menos é isso que se espera!

\section{REFERENCIAS}

A CRISE afeta nosso sentimento democrático, diz ministro da Justiça no II Congresso Internacional de Direito Eleitoral. Tribunal Regional Eleitoral de São Paulo. São Paulo. Disponível em: <http://www.tse.jus.br/legislacao/codigo-eleitoral-anotado/codigo-eleitoral>. Acesso em 21 set. 2016.

ARISTÓTELES. Os pensadores. v. I. São Paulo: Nova Cultural, 1991.

A Política. São Paulo: Ícone Editora, 2007.

BOBBIO, Norberto. O futuro da democracia: uma defesa das regras do jogo. Rio de Janeiro: Paz e Terra, 1986. 
BORÁ tem mais eleitores do que moradores. botucatublogger, Botucatu. Disponível em: <https://botucatublogger.blogspot.com.br/2016/08/bora-tem-mais-eleitores-doquemoradores_31.html\#.V83_SZgrK00>. Acesso em: 5 set. 2016.

BRASIL, LEI No 4.737, DE 15 DE JULHO DE 1965. Disponível em: <http://www.tse.jus.br/legislacao/codigo-eleitoral/codigo-eleitoral-1/codigo-eleitoral-lei-nb04.737-de-15-de-julho-de-1965>. Acesso em 19 set 2016.

BRASIL, LEI No 10.406, DE 10 DE JANEIRO DE 2002. Disponível em: <http://www.planalto.gov.br/ccivil_03/leis/2002/L10406.htm>. Acesso em 19 set 2016.

BRASIL, LEI $\mathrm{N}^{\mathrm{o}}$ 3.071, DE $1^{\circ}$ DE JANEIRO DE 1916. Disponível em: <http://www.planalto.gov.br/ccivil_03/leis/L3071.htm>. Disponível em: Acesso em 19 set 2016.

BRASIL, CONSTITUIÇÃO DA REPÚBLICA FEDERATIVA DO BRASIL DE 1988. Disponível em: <http://www.planalto.gov.br/ccivil_03/constituicao/constituicaocompilado.htm> Acesso em 18 set 2016.

BRASIL, Tribunal Superior Eleitoral - TSE Disponível em: < http://www.tse.jus.br/> Acesso em 25 set 2016.

CANDIDO, Joel José. Direito Eleitoral Brasileiro. ed. re., atual. e ampl. -Bauru, SP: edipro, 2003.

CERQUEIRA, Thales Tácito Pontes Luz de Pádua. Direito Eleitoral Brasileiro. Belo Horizonte: Del Rey, 2002.

CRUET, JEAN. A vida do direito e a inutilidade das leis. 2 ed. Leme-SP: EDIJUR.2003.

DE MELLO, Celso Antônio Bandeira. Controle do poder político. In: Revista trimestral de direito público, São Paulo, jul./set. 1995.

. Conteúdo jurídico do princípio da igualdade. 3 ed. São Paulo: Malheiros, 2005.

. Discricionariedade e controle jurisdicional. 2 ed. São Paulo: Malheiros, 2006.

DALLARI, Dalmo de Abreu. Elementos da teoria geral do Estado. São Paulo: Saraiva, 2007.

DINIZ, Maria Helena. Curso de direito civil brasileiro: teoria geral do direito civil. v. 1. São Paulo: Saraiva, 2015.

FORTE, Breno Soares. Reinterpretando a questão do domicílio eleitoral. Revista eleitoral TRE/RN - Volume 24, 2010. Disponível em: <www.trers.jus/arquivos/FORTE_Domicilio.PDF>. Acesso em 21 set 2016.

GAGLIANO, Pablo Stolze; PAMPLONA FILHO, Rodolfo. Novo curso de direito civil: parte geral. São Paulo: Saraiva, 2013.

GOMES, JOSÉ JAIRO. Paradigmas atuais do Direito Eleitoral. Tribunal Regional do Rio Grande do Sul $\quad-\quad$ TRE/RS. Disponível em < 
http://www.trers.gov.br/arquivos/GOMES_paradigmas_direito_eleitoral.pdf>. Acesso em: 25 set 2016.

GRASIELA, Lilian. Prefeitura de Iacanga questiona título de eleitor para acampados. jcnet,Bauru. Disponível em: <http://www.jcnet.com.br/Regional/2016/04/prefeitura-deiacangaquestiona-titulo-de-eleitor-para-acampados.html>. Acesso: em 03 set. 2016.

GOMES, Orlando. Introdução ao direito civil. Rio de Janeiro: Forense, 1996.

GONÇALVES, Carlos Roberto. Direito civil brasileiro: parte geral. São Paulo: Saraiva, 2015. v. 1. LORA ALARCON, Pietro de Jesus. Ciência política, Estado e direito público: uma introdução ao direito público da contemporaneidade. São Paulo: Verbatim, 2014.

LUCHI, Alberto Fulio. O conceito de domicílio e sua aplicabilidade nos âmbitos

Constitucional, civil e penal, à luz dos ensinamentos de Dinorá Grotti. Site Arruda Alvim e Thereza Alvim Advocacia e Consultoria Jurídica. Disponível em: <www.arrudaalvimadvogados.com.br>. Acesso em 20 set. 2016.

MADEIRA, ARNALDO. Projeto de Lei do Sr. Arnaldo Madeira, de 2009. Câmara dos Deputados. Brasília. Disponível em < http://www2.camara.leg.br/>. Acesso em: 25 set 2016.

MARIA HELENA DINIZ, Curso de Direito Civil Brasileiro, $1^{\circ}$ volume, 8 ed., São Paulo, Saraiva, 1990-1991, p. 108.

MELO FILHO, Luiz Gonzaga Pereira de. O Direito Eleitoral e sua Evolução Histórica. Conteudo Juridico, Brasilia-DF: 15 out. 2013. Disponível em: <http://www.conteudojuridico.com.br/?artigos\&ver=2.45516\&seo=1>. Acesso em: 22 set. 2016.

MENDES, Gilmar Ferreira; BRANCO, Paulo Gustavo Gonet. Curso de direito constitucional. São Paulo: Saraiva, 2014.

MONTEIRO, Washington de Barros. Curso de direito civil: parte geral. v.1. Atualização de Ana Cristina de Barros Monteiro Franca Pinto. São Paulo: Saraiva, 2012.

NADER, Paulo. Introdução ao estudo do direito. Rio de Janeiro: Forense, 2013. v.1.

ROUSSEAU, Jean-Jacques. O contrato social. São Paulo: edipro, 2013.

PEREIRA, Caio Mário da Silva. Instituições de direito civil: introdução ao direito civil, teoria geral do direito civil. Rio de Janeiro: Forense, 2005. v. 1.

PONTUAL, Helena Daltro. Uma breve história das Constituições do Brasil. Senado Federal. Disponível em: < http://www.senado.leg.br/noticias/especiais/constituicao25anos/historiadasconstituicoes.htm >. Acesso em 18 jul. 2017

ROTHENBURG, Walter Claudius. Direitos Fundamentais. São Paulo: Método, 2014.

SILVA, José Afonso da. Curso de direito constitucional positivo. 36 ed. São Paulo: Malheiros, 2013.

SILVA, De Plácido e. Vocabulário Jurídico, volume I, 3 Ed., Rio-São Paulo: Forense, 1973. 
TAVARES, André Ramos. Curso de direito constitucional. São Paulo: Saraiva, 2007.

VENOSA, Silvio de Salvo. Direito civil: parte geral. v. 1. São Paulo: Atlas, 2015. 